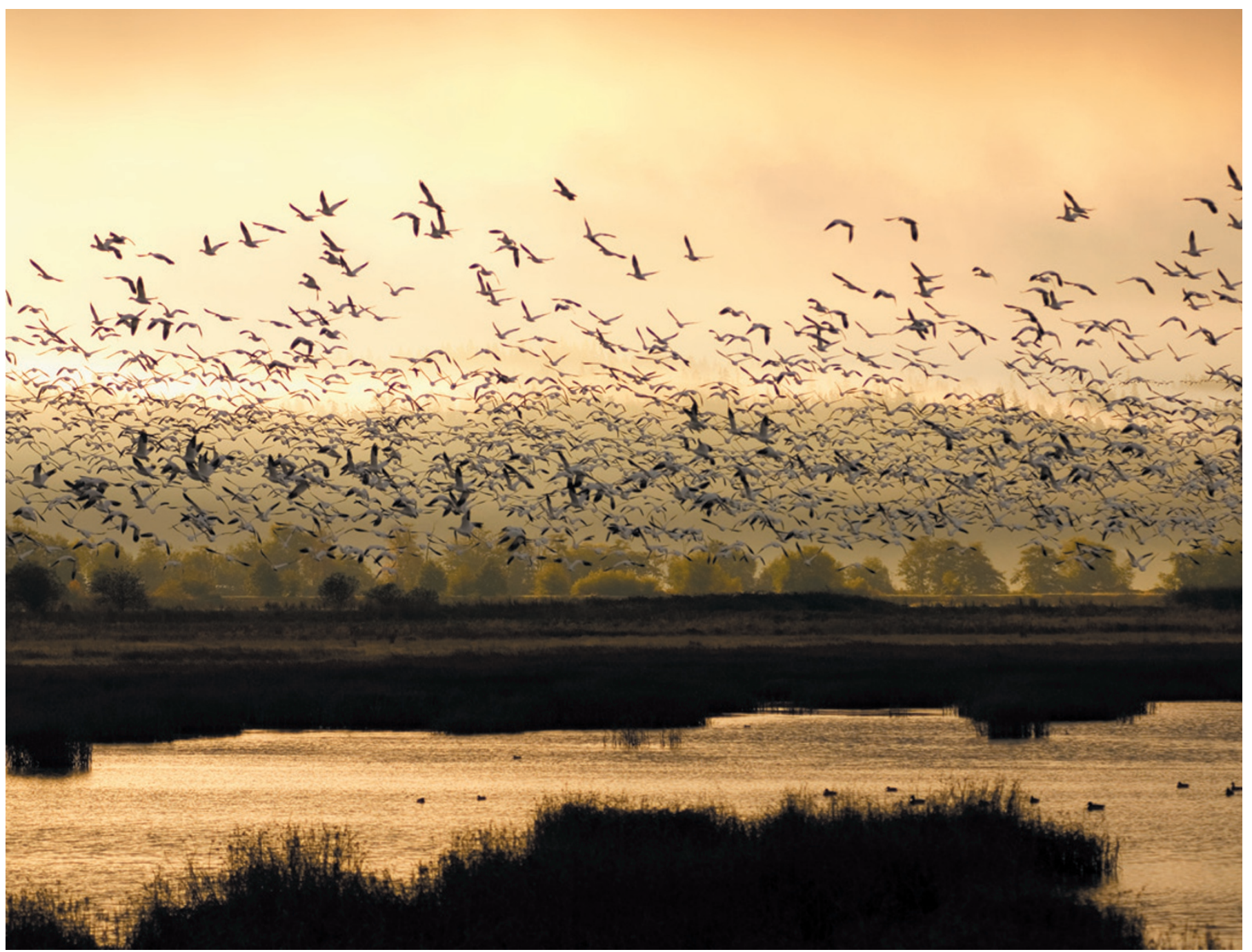

ENVIRONMENT

\title{
New words on the wild
}

\section{Robert Macfarlane reflects on the recent resurgence in nature writing.}

“I don't know anything else worth saving," rages the hero of The Monkey Wrench Gang (1975) about the wilderness. Edward Abbey's novel went on to inspire the 1980 formation of eco-activist group Earth First!, whose members undertook direct-action campaigns aimed at preserving wild places. "No compromise in defence of Mother Earth!" was the group's original pledge.

Abbey's novel was fuelled, like his memoir Desert Solitaire (1968), by fury at the despoliation of the landscapes he loved. The book formed part of an extraordinary surge of writing about nature in North America in the 1970s and 80s. Annie Dillard's visionary Pilgrim at Tinker Creek (1974), about life and death in the Blue Ridge Mountains of
Virginia, won the Pulitzer Prize in 1975; 11 years later, Barry Lopez's exploration of the American far north, Arctic Dreams (1986), became an instant classic and long-term best-seller.

Over the past 15 years, Britain has experienced a comparable surge with the blossoming of a literary form that has become known as 'new nature writing'. The tone of this form, however, feels far from the roustabout activism of Abbey, or even the puckishness of Dillard. The genre is distinguished by its mix of memoir and lyricism, and specializes in delicacy of thought and precision of observation. A number of these books have drawn massive acclaim from critics and readers: Roger Deakin's Waterlog (1999), a sparkling account of his 'swimmer's journey' through the lakes and rivers of the British Isles; William Fiennes's The Snow Geese (2002), about flight, home and happiness; Nature Cure (2005) by Richard Mabey, who describes the role of the outdoors in his recovery from depression; and Olivia Laing's To The River (2011), a fluent meditation on place and memory inspired by the River Ouse in Sussex.

It is widely agreed that Britain is going through a golden age of nature writing, but no one seems sure quite how to define it. Ragtag, wayward and polymorphous, it folds in aspects of memoir, travel, ecology, botany, zoology, topography, geology, folklore, literary criticism, psychogeography, anthropology, conservation and even fiction. Most distinctive, to my mind, is its tonal mix 
of the poetic and the scientific and analytical. The Snow Geese, for instance, combines exquisite accounts of geese in flight - "the flock lifted from the field as a single entity, 10,000 pairs of wings drumming the air, as if people were swatting the dust from rugs" — with an inquiry into the biomechanics of avian migration.

Even this aspect of new nature writing, though, is hardly new. In the decade after the Second World War, US scientists Rachel Carson and Loren Eiseley, and pioneering conservationist Aldo Leopold - author of A Sand County Almanac (1949) - became famous for the intimate tone and ethical commitment of their essays. They were "imaginative naturalists", to borrow the subtitle of Eiseley's million-selling The Immense Journey (1957). Their appeal lay in their fusion of the latest research with firstperson narrative.

\section{CONTINENTAL DIVIDE}

North America has always been a happier habitat for nature writing than Britain, perhaps because the vast and various geography of the continent - from southern canyon lands to northern polar tundra - has provided limitless inspiration. For much of the twentieth century in the UK, writing about wildlife or the countryside was regarded with suspicion tending to contempt. Stella Gibbons parodied rural writing in Cold Comfort Farm (1932): "Daisies opened in sly lust to the sun-rays and rain-spears, and eft-flies, locked in a blind embrace, spun radiantly through the glutinous light.... And Evelyn Waugh skewered the plush prose of country diarists in his novel Scoop (1938), with sentences such as "Feather-footed through the plashy fen passes the questing vole".

For decades after Gibbons and Waugh, nature writing seemed in abeyance, dismissed as either reactionary or soppy in its longing for oneness with the natural world. This didn't prevent the emergence of occasional masterpieces: J. A. Baker's The Peregrine (1967), for instance, inspired — as in part was Carson's Silent Spring (1962) by Derek Ratcliffe's landmark studies into the effects of pesticides on eggshell-thinning in British raptors. There was also Nan Shepherd's glorious meditation on place and being, The Living Mountain (1977), born of years of acquaintance with the Cairngorm massif of north-east Scotland.

Why, then, has nature writing enjoyed its recent renaissance in Britain? Two main causes suggest themselves. The first is disembodiment: people are spending increasing amounts of time in atmospherecontrolled environments, hunched at keyboards. An inevitable consequence of this has been a longing for wildness and nature: the feel of wind and sun upon the face, or the sight of a stooping falcon, or of an oak tree in spring leaf. Or, as Henry David Thoreau cried - having laid his hands on the summit rocks of Mount Ktaadn in Maine - for "Contact! Contact!"

The second context is global crisis. It is no coincidence that a literature celebrating the natural world should have emerged at a time when the natural world is so conspicuously under threat. The past 15 years have seen the Deepwater Horizon blowout in the Gulf of Mexico, the break-up of the Antarctic ice shelf, widespread habitat destruction, further evidence that we are living through the sixth great extinction pulse, and the slowmotion emergency of climate change.

British nature writing is energized by this sense of menace and hazard. The biodiversity crash has been tackled boldly by Melanie Challenger in On Extinction (2011), and wittily by Caspar Henderson in The Book of Barely Imagined Beings (2012). Henderson records some of the extraordinary species with which we share the planet (including the mantis shrimp Gonodactylus, which "has the fastest genitals in the West and will use them to smash your head with massive force"). Meanwhile, Esther Woolfson's Corvus (2008) and Field Notes From A Hidden City (2013) examine interspecies relationships and the responsibilities we bear to the creatures that surround us (echoing Leopold's 'land ethic').

A sense has emerged that nature writing might almost provide salvation. "If we are to continue to live with birds about us we need bird poems as much as the RSPB [Royal Society for the Protection of Birds]," notes ornithologist Tim Dee, author of The Running Sky (2009). And Margaret Atwood hopes her novels might "move public opinion in a more biospherefriendly direction". Nature writing to the rescue!

I am less sure. The Anthropocene is a frightening and forceful era. I wonder, really, what literature can do in the face of population pressure, rising sea levels, deforestation and the rapacious instinct of capital. A few years ago a monograph by the American academic John Felstiner, was entitled Can Poetry Save The Earth? (2009). "No!" I yelled silently at the cover when I first saw it, "Of course it can't!" On reading the book, I was curiously relieved to find that this was also Felstiner's answer.

There are good reasons not to exaggerate the possible consequences of nature writing. One is that it often preaches to the converted: the people it reaches tend to be those with the most developed environmental consciences. "Sceptical readers," as the American farmer and writer Verlyn
D NATURE.COM To hear Robert Macfarlane talk about travel writing: go.nature.com/bnclea
Klinkenborg observed, "seldom pick up this kind of writing, or submit to its evidence." Another reason is that nature writing can often feel too pious and gentle in its urgings - the green equivalent of attending Sunday school.

And yet a law of unintended consequences has always governed literature, as The Monkey Wrench Gang made clear. Writing that aims to provoke specific behaviours has a name: propaganda. And writing that seeks to provoke specific emotions also has a name: kitsch. Literature, by contrast, does not deal in deliverables. It stirs the sediments of thought and morals, setting them strangely aswirl.

"Transformation comes about as much because of pervasive changes in the depths of the collective imagination as because of visible acts, though both are necessary," says Rebecca Solnit, one of today's most interesting US essayists and environmental activists. "And though huge causes sometimes have little effect, tiny ones occasionally have huge consequences." The history of environmental literature is rich with such fascinating 'transformations': naturalist John Muir's influence on the founding of US national parks, "There or the thunderclap are good reasons not to exaggerate the possible consequences of nature writing." publication of Silent Spring, with its consequences for use of the pesticide DDT (dichlorodiphenyltrichloroethane). As yet unmapped is the influence of Cormac McCarthy's The Road (2006), a novel that chilled me to the core and that British journalist George Monbiot has described as "the most important environmental book ever written".

For literature possesses certain special abilities, very different to those of science. It can convey us into the minds of other people, and even - speculatively - the minds of other species. It can help us to imagine alternative futures and counter-factual pasts. It is content with partial knowledge in ways that science is not. Crucially it can, in author and environmentalist Bill McKibben's phrase, make us feel things "in the gut" - fear, loss and damage, certainly, but also hope, beauty and wonder. And these last are, I think, the most important emotions in terms of our environmental future: our behaviour is more likely to be changed by promise than by menace. We will not save what we do not love.

Robert Macfarlane is a fellow of Emmanuel College, Cambridge, UK, and author of Mountains of the Mind, The Wild Places and most recently, The Old Ways. 